\title{
Organizational Integrity of Administrators of Divine Word Colleges in Region I, Philippines and Employees' Job Satisfaction As Perceived by the Employees
}

\author{
Article by Fr. Damianus Abun ${ }^{1}$, Alfie P.Racoma ${ }^{2}$ \\ ${ }^{1}$ PhD Faculty of the College of Business of Diviene Word College of Vigan, Philippines \\ ${ }^{2}$ MST-Physics, Faculty of the college of Education of Divine Word College of Vigan, \\ Philippines \\ E-mail: frdamy@yahoo.com
}

\begin{abstract}
The study was to determine the level of integrity of administrators of Divine Word Colleges in Northern Province, Philippine, and determine the effect of organizational integrity and job satisfaction of employees. It was found that overall, the integrity of administrators were at the moderate or good level. It was also established that the level of integrity of administrators influence employees' job satisfaction. Such relationship concludes that employees' job satisfaction is not just caused by monetary reward but how the administrators carry out their duties and responsibilities in an ethical manner.
\end{abstract}

Keywords: Integrity, job satisfaction, self-integration, maintenance of identity, standing up for something, moral purpose.

\section{The problem}

\section{Rationale}

The performance of the organization/business or school does not only depend on how much capital (money) you invest in the school/company. Or it does not depend only on the managerial skills of the administrators/managers but it also depends on many aspects of organization life. Therefore, paying attention to the details of organization life is necessary, not only on physical matters or tangible things but the things that we cannot see such as the values of leaders/managers or administrators and employees. Values may be insignificant in the eyes, but if they are not given serious attention, they can be a big hindrance to the development of the organization.

People often focus on big things or big issues such as efficiency, transparency, managerial skills, strategic plan, leadership skills together with their technical skills in carrying out their duties and responsibilities but one aspect that people often undermine is the values, particularly the moral values of those who lead, those who are on the top of the organization. The motivation of employees to work is not just caused by money but it is also caused by other factors such as employee's treatment and organizational climate as a whole (McShane, 2000). Moral values that are being practiced by the organization are considered as one of the sources of motivation.

One of moral values that are often undermined is integrity. Such value may be considered insignificant to some and therefore it is often ignored, if not forgotten and taken for granted. However, though it may be insignificant but the effect of ignoring it can cause a tremendous impact on the organization. The administrators/managers often committed mistake by focusing on the big picture such vision; mission, objectives but small factors that contribute the achievement are neglected. The foundation of management should be solidly founded on integrity.

Value of integrity is often written in the handbook of the organization/business or schools as their core values. Value of integrity may seem to be small in our eyes but it has a tremendous power to bring down or up the organization. We may mention several examples of successful companies that have applied integrity as one of their values namely Accenture and Barness \& Noble Booksellers. These companies have been included in the Fortune 500 Company (http://fortune.com/video/2016/03/04/best-companies-to-work-for-hospitals/) because of their success stories and their success stories can never be achieved with practicing the value of integrity. We also 
mention several companies that went into trouble such as ENRON and WorldCom. Their bad stories were caused by some wrong behavior which we may call it "lack of integrity (Edmonds, 2001, Gison, 2008). Somehow based on the report, the managers and accountants committed fraud in their financial reporting that misled the public and investors. Those are just examples of having no integrity in managing a business. It has been always the reason that bankruptcies are caused by criminal CEOs. The criminal CEOs are not following the rule of law and ethical practices (Howe 2011).

Since moral values are important part of running the organization/business or school, thus the study would focus on one of the moral values which are the value of integrity. The study would like to determine the level of organizational integrity of administrators who manage the schools and the effect of living the integrity to the job satisfaction of employees. The study wants to find out if the exercise of such value in the management practices will directly affect the job satisfaction of employees. Several studies along this topic have been conducted but in the companies not run by religious organization and there have been no studies on the same topic conducted in the school context, much more in the Catholic run schools.

This study gives attention to the Catholic schools because Catholic schools are supposed to be the formation center of moral values. Formation of moral values may not necessarily take place through teaching but it is also shown and taught through management practices, the way how administrators manage day to day operation. It is expected that teaching must integrate moral values in their curriculum and management practices must reflect moral values. Along such idea, the study would like to know if those who are leading and managing the schools are espousing value of integrity in their management practices. The series of Vatican document on "The Sacred Congregation for Catholic Education" (2012) pointed out that the general purpose of a school is integral formation by means of a systematic and critical assimilation of culture. Integral formation is not just about intellectual capability but it is also about moral character. Such formation cannot be done by just delivering information's or knowledge to the students but through personal contact with the students. Such concept is also pointed out by the Second Vatican Council Document (1982, no. 115) about the Catholic Schools and Salvific Mission of The Church. It emphasizes the great importance of the contribution of the Catholic Schools in the total formation of the whole man. Such formation is not limited to psychological development but also moral development. Such concept is reflected in the Code of Canon Law (1983), the law of the Catholic Church which states that true education must strive for complete formation of the human person. Those documents practically emphasize the same point that schools are center for moral formation. This is the main interest of this study which is to find out moral values such integrity is highly observable and lived in these Catholic Schools.

\section{Theoretical framework}

Integrity has been part of core values in any organization. However, not many organization' members really understand the meaning of integrity and how integrity works and influence the organization. Integrity is a moral value which is abstract and can only be seen in action. To provide basis for our study, let us find out the meaning of integrity and how it affects the organization and how integrity affects the satisfaction of employees.

\section{Integrity defined}

Originally the word "integrity" was used only for material object which means wholeness or intactness. It is a condition in which an object is not damaged or corrupted. Such meaning later on is used for human persons. Integrity is used as a virtue; it refers to a quality of a person's character. A person of integrity is then defined as a person who has not been damaged inside -out by wrong doing or immoral act. Thomas More (1633as cited by Nillsen (2005) has used the word integrity which meant wholeness which means moral soundness. Moral soundness refers to strong moral principle specifically uprightness, honesty and sincerity. To expand our concept of integrity, we are going to see different concepts of integrity offered by different philosophers.

Condit \& Caudill (1999) defines integrity as consistency of actions, values, methods, measures, principles, expectations and outcomes. Integrity in their case refers to consistency, in the sense that there should be no alteration or flip-flopping. Such understanding then is associated with honesty and 
truthfulness or accuracy of one's actions. Thus, it is now considered as a moral character. A person of integrity now means a person who has not been broken by immorality. Stemming from such understanding, integrity is connected to acting morally. In this case, there is substantive aspect on what it is to act with integrity (Stanford Encyclopedia of Philosophy, 2011). Substantive integrity is wholeness or intactness of a person. What you see from the outside is a reflection of what is inside you. The inner moral values of the person and actions of the person are jibed, in coherence. Inside and outside of the person is the same. His/her action is a reflection of his/her inner values. Word and action are one, inside and outside are one. Such view indicates that a good action is originated from a good intention, good heart, and good mind. One can read a person, what kind of person he/she is, from the action. Integrity then is necessarily seen in action and it is through action we can evaluate if such person is a person of integrity or not.

In the development of the discussion of integrity, Cox, Case, and Levine (2017) as cited from Frankfurt (1987) classified integrity as the integration of self, integrity as maintenance of identity, integrity as standing for something, integrity as moral purpose and integrity as a virtue (Stanford Encyclopedia, 2013, 2017) . Integrity as self-integration means keeping the self-intact and uncorrupted (wholeness/intactness). In this sense, integrity is a condition of unbrokenness. According to them, a wholly integrated person is a person who acts without any conflicting desires or person who constitute themselves without ambivalence. In terms of integrity as maintenance of identity, integrity means a person's holding steadfastly true to their commitment, (Frankfurt 1987). A person of integrity in this sense is the one who committed to people, institution, traditions, causes, ideals, principles, jobs/ duties and so on. However, commitment in this case is not just any commitment because people can be committed to a certain act that is not good or even immoral. Bernard Williams (1973) argued that integrity in terms of the commitment means commitment to what is most deeply, and fundamental to one's life. In that sense, to abandon integrity is to abandon what is fundamental to one's life, to abandon what gave him/her identity or virtuous character. Therefore, integrity in this case is a virtue. A virtue motivates a person to act in desirable ways or it enables a person to act in desirable ways. A person of integrity is a person who can act in a way that reflects his sense of who he is/she is, who acts from her/his motives, his/her interest and commitments that are her/his own (Williams, 1981). The questions here are: what are those commitments, motives, and interests because commitments, motives and interest can be anything either is good or bad? Cox, Caze and Levine (2003) answered that those commitments, motives and interest must be expressions of great moral values (Stanford Encyclopedia, 2017).

Deepening further the discussion of integrity, Colhoun (1995) tries to view integrity as a social virtue. As a social virtue, integrity is defined only in relation to the others, in the sense that integrity cannot be understood if it is not lived in the social context. Such value exists and understood because of one's relation to the others. In this case, the integrity of a person can only be understood and seen in his/her relations with the other in the community. Colhoun (1995) pointed out that "integrity is not just a matter of a person's proper regard for their own best judgment but a person of integrity stands for his/her best judgment within a community. A person of integrity treats their own endorsement as ones that matter or ought to matter to fellow deliberators". In this case, a person of integrity is committed to what is best, not only for himself but also for the community. The person stands for what is good for the community and does not lie to his own statement/decision, concealing them, recanting them under pressure, selling them out for rewards or changing stand under pressure. He stands for what he/she believes to be best not only for him/herself but also for community. Therefore, Halfon (1989) later argues that integrity has a moral purpose. It is not just for the sake of integrity itself but a person of integrity in this case is a person who dedicates to pursue moral life by living up their moral principles and commitment to others. He/she is pursuing a commitment to do what is best morally.

\section{Integrity in organization}

The application of integrity is not just within the sphere of individual life but it is within the social context or social domain. Integrity is not just an individual values but a value that has to be lived in the community or in the organization where one relates himself/herself to the others. Therefore, we 
want to see how integrity is being practiced in the organization or in the school context. School is also an organization with its special character and purpose. Thus, when we talk about organization in this paper, we refer it to school. Integrity that we discuss in this study is integrity in the school context.

When we talk of organizational integrity, we cannot avoid of talking personal integrity because organization is composed of individual persons and these may include administrators and employees. We cannot deny that integrity of those who run the organization can affect the integrity and the image of the organization. Thus, administrators or managers must acknowledge their role in shaping organizational ethics and seize this opportunity to create a climate that can strengthen the relationships and reputations on which their companies' success depends (Paine, 1994). In this case, integrity is indispensable, it is hard to ignore. In short, not living and practicing integrity can lead to bankruptcy. Managers, in this case, are the first one to live such value in their decisions because if they do not, then they run the risk of personal and corporate liability. Such view supports our belief that individual integrity matters to organizational integrity. What does it mean? When the managers do not live moral lives, do not live by their moral example, they can affect the values of the employees. Do not expect employees to be moral when the managers are not. Along such concept, Dugar (n.d) argued that "at the corporate level it takes individuals of integrity to develop a consensus around shared values. As this consensus builds, the corporation develops a culture of integrity. A culture of integrity creates a highly valued work environment; it impacts the quality of corporate governance; and it provides a foundation for solid long-term financial performance". In other words, the organizational integrity is derived from individual integrity. Verhezen (2008) confirmed such link between organizational integrity and individual integrity as he argues that individual integrity reinforces organizational integrity. At this level, all employees of the organization adhere to moral principles despite pressure or personal temptations (Adler \& Bird, 1988). Now integrity gains respect in concrete situation in relationship with others and within the community or organization.

Along with the stated idea above, we can say that integrity failure in an organization is originally caused by character flaws of the responsible individual. The responsible individuals are managers. Most of the time, they do not discern what is morally appropriate and what is not in their daily decisions. Most decisions are not based on good motives and good purpose, but driven by self-interest and sadly their wrong values affect the rest of the organization which consequently destroys organizational integrity (Rodrigues, 2007). Thus, organizational integrity becomes a social virtue that emphasizes connectedness with a large purpose. A manager of high integrity must act according to moral principles and values that relate to other members of the organization (Becker, 1998). In other words, organizational integrity is a standard of personal moral excellence (Habermas, 1998) of all people working within the organization. Managers' job is to see to it that all employees are guided by the moral principles, guided by the moral value adopted by the organization. There should be no possible internal conflict between personal values and organizational value.

It is therefore necessary to create an environment where employees are encouraged to live the value of integrity. The organization needs to express those values in normative statement which can be included in the organization's mission statements (Paine 2003). However, even though an organization has organizational values, it does not guarantee that all employees will act according to the stated organizational values. One needs attitude of integrity that not only follows the letter of the rules but adheres to deeply held and internalized ethical values. In this case, leadership maintains organizational ethos in relation to collective mission, identity and long term objectives. The most challenging is when managers or administrators are confronted with competing and ambiguous demands. In such situation, a person of integrity needs to make a decision about right versus right, inevitably leading to certain compromises that do not undermine integrity (Badaracco, 2002).

\section{Integrity and the bankruptcies}

Stories coming from other parts of the world are enough evidence for us to tell that value of integrity is crucial to the survival of the organization. It has been the reality that not living the integrity means the collapse of the organization. The story of several big corporations such as ENRON, WorldCom, Parmalat, Waste Management, Qwest Communications, Tyco International, AIG, and Satyam Computer Services, Adelphia Communications, AOL Time Warner and many more 
are enough evidence to tell us that it is time to give attention to the value of integrity. All these companies are brought down not because of capital inadequacy but because of fraud. The managers and the auditors are conniving to mislead the public by not telling the truth about the financial situation of their companies (Patsuris, 2002). The lack of integrity which is indicated by poor governance led directly to the demise of Enron and Andersen (Veherzen 2008). The collapse of those organizations does not only destroy the organization itself but even personal reputations of board members and management.

Just by knowing what happens to those companies and ask why, we simply say that they cheated, they lied or they were not honest. The prize of being dishonest was so expensive. Their stories tell us that the bottom line of bankrupt stories is the lack of integrity. Solving bankruptcy is in the first place to manage integrity. Managing integrity is to manage individual integrity and individual integrity management is a way to build organizational integrity. It is only through such consensus; the corporation can develop a culture of organizational integrity. As argued by Duggar (n.d) that a culture of organizational integrity creates a highly valued work environment for the employees, pride of being part of the organization and improve the brad image of the organization. Consequently it provides a foundation for solid long-term financial performance.

Besides financial reward, organizational integrity creates a great place to work. Great Place to Work Institutes, Inc. (n.d) pointed out trust and integrity as the essential factor to create great workplace to work. It maintains that trust and integrity contribute positively to the bottom-line. When these values are being practiced in the organization, employees would be happy to be part of the organization and it can lower turnover rates. Beyond that, it will be easy for the company to recruit qualified applicants, and have better employee morale. Such environment indirectly or directly generates higher earnings and high performance (GPWI, n.d.).

One may conclude that practicing dishonesty can destroy the workplace environment and it can cause short term and long term consequences. Short term consequences include employees' dissatisfaction, employees' demoralization and work performance. Long term consequence may lead to bankruptcy. But what is frightening is not just financial bankruptcy but moral bankruptcy, the bankruptcy of society or the organization. It is a state of being devoid of morality and ethics for business. As O, Connor (2014) put it, "it is the state a person reaches when he trades away or violates too many of his core moral values and commitments. He may also lose important relationships either as a cause or consequence of his loss of moral commitments. Someone who is morally bankrupt may or may not recognize that he has reached this state".

\section{Job satisfaction}

Job satisfaction is the output of how people feel toward its job. It is how much workers like or dislike their jobs. There have been a lot of theories related to job satisfaction. We recall the five hierarchy needs of Maslow, Herzberg theory and many more. Job satisfaction is a product of the fulfillment of different needs which is produced by the work. The needs must be met and the needs that create job satisfaction are not only physical needs but also psychological needs. In terms of physical needs, it can be identified such as basic needs and wants, however, when it comes to psychological needs, it is hard to pinpoint exactly what exactly those needs are, given the fact that humans are different in nature. Psychological needs encompass many aspects of life and many factors either internal or external can affect psychological needs. Thus the term "job satisfaction" is understood to mean everything from "making all aspects of a job easy for employees" to "making the job meaningful, significant and challenging." Even such description is still limited because aspects of jobs are not the only ones that make people happy but there are unrelated aspects to job that makes people happy. In other words, we can say that all the factors contributing to employee motivation and effectiveness are not captured in any one of the single ambiguous concepts of job satisfaction. Thus, much of the quantitative research has not been verified by qualitative data. Research conducted by Schleicher, Watt and Greguras (2004) for example, indicated that individuals with identical responses to questions on job satisfaction often possess entirely different behaviors relating to job performance. Additionally, differing factors relating to job satisfaction hold varying degrees of importance to individuals. Thus, a proven model showing the relationship between job satisfaction and performance 
has been elusive despite the vast quantity of qualitative data supporting the relationship. These issues are very complex and have simply not been fully deciphered by researchers.

Scheid (2010) argued that although job satisfaction, employee motivation and productivity are complex and confusing issues, management should not stop finding out how to improve job satisfaction. It is important to understand them and find out why so. Understanding the reasons of job dissatisfaction and motivation should temper your approach to improving job satisfaction. It is recommended therefore that managers should focus on two areas to improve job satisfaction and they are motivation and productivity. The two factors refer to how employees are treated and the content of their work. Managers must monitor the effect of their management practices through feedbacks. A good employee survey should help management focus in on areas which are creating dissatisfaction or which are not providing adequate motivation.

Many researchers have identified tangible ways on how to improve job satisfaction. Benefits have been always identified as one the sources of satisfaction or dissatisfaction. Only few researchers have identified job satisfaction or dissatisfaction to intangible factors such as behavior or treatment. According to Voon (2010), organizational success depends on the leaders of the organization and their leadership styles. By adopting the appropriate leadership styles, leaders can affect employee job satisfaction, commitment and productivity. Narasimhan \& Lawrence (2011) also emphasized leader's behavior and style influence employees' perception over their leaders and such situation leads to desirable workplace outcomes. Beyond leadership styles, Xiao (2008) pointed out that work values have something to do with job satisfaction. Work values are related to various facets of job satisfaction, which in turn influence employees' commitment to the organization.

\section{Conceptual framework}

In assessing the relationship between administrators' integrity and job satisfaction of employees of Divine Word Colleges in SVD Northern Province as perceived by the rank and file, the concept of the study revolved in the paradigm wherein independent variables are self-integration, maintenance of identity, standing up for something, and moral purpose. While dependent variable is job satisfaction of employees. The paradigm reflects the relationship between the administrators' integrity in terms of self-integration, maintenance of identity, standing up for something and moral purpose and employees' job satisfaction.

Independent Variable

\section{Dependent Variable}

\begin{tabular}{|l|l|}
\hline Administrators' Integrity: & The level of employees' Job \\
1. Self-f-Integration \\
2. Maintenance of identity \\
3. Standing for something \\
4. Moral Purpose
\end{tabular}

\section{Statement of the problem}

The study aims to determine the impact of organizational integrity as reflected through its administrators and employees' job satisfaction.

Specifically it seeks to answer the following questions:

1. What is the level of organizational integrity of administrators of Divine Word Colleges in the Northern Province in terms of self-integration?

2. What is the level of organizational integrity of administrators of Divine Word Colleges in Northern Province in terms of maintenance of identity?

3. What is the level of organizational integrity of administrators of Divine Word Colleges in Northern Province in terms of standing up for something?

4. What is the level of organizational integrity of administrators of Divine Word Colleges in the Northern Province in terms of moral purpose?

5. What is the level of job satisfaction of employees of Divine Word Colleges in the Northern Province?

6. Is there no relationship between the organizational integrity and employees' job satisfaction? 


\section{Assumptions}

The study is guided by the following assumptions:

1. The administrators of Divine Word Colleges in the Northern Province possess and live the value of integrity.

2. Integrity does affect job satisfaction of employees.

3. The questionnaires used in the study are valid.

\section{Hypothesis}

The study is guided by the following hypothesis:

1. There is no relationship between value of integrity and job satisfaction of employees

\section{Scope and delimitation of the study}

This study is limited to measure the relationship between organizational integrity and employees' job satisfaction of the Divine Word Colleges in the Northern Province as perceived by the employees. The organizational integrity that is being measured is the integrity of administrators. Those administrators were Divine Word Missionaries who were working in different Colleges and Lay Partners. There will be four aspects of integrity to be measured: the integration of self, integrity as maintenance of identity, integrity as standing for something, integrity as moral purpose and integrity as a virtue as presented by Cox, Caze and Levine, Stanford Encyclopedia,2017) .

\section{Related literature and studies}

\section{Related literature}

\section{On integrity}

Integrity emerges from the literature as a feature of both conviction and personality. At its most neutral, it is identified with coherence between one's convictions/one's words, and one's actions. The word alone is associated with ethics. Ethics and integrity are often used interchangeably but they are clearly different. Ethics are the moral behaviors prescribed by society or culture that determine "good" and "bad" of conduct for its society or organization members (Pojman, 1995 as cited in Kaiser \& Hogan, 2010). While integrity is the moral attribution we apply to one's observed behavior (Kaiser \& Hogan, 2010). Scherkoske (2010) in his essay on Integrity and Moral Danger argued that persons of integrity are a person who is consistently living his moral values in every day's life and such consistency merit respect. Two influential accounts suggest why. Bernard Williams as cited by Scherkoske (2010) emphasized that integrity is 'a person's sticking by what she/he regards as ethically necessary or worthwhile. People without integrity trade action on their own views too cheaply for gain, status, reward, approval or for escape from penalties, loss of status, disapproval.

Consistently in line with what we have discussed at the earlier part of this paper, integrity is becoming also a social value because it is only understood in the social context such as community or organization. Such value is not only the value of individual person but it is also attributed to organizations. In this case, though originally integrity is personal value but it becomes the value of the organization in which all individual persons who are working in and for the organization are living the value of integrity. Srivastva (1988) on her book, "Executive Integrity: The Search for High Human Values in Organizational Life", shows that executive integrity is not merely a moral trait but a dynamic process of making empathetic, responsible, and sound decisions. Key features of executive integrity include effective social interaction, open dialogue, and responsive leadership. Such value is not just for one self but it should be displayed through action in every day's management practices and such consistent moral action can radiate around the organization to inspire more employees to follow and finally it can improve the image and performance of the organization.

Along such line of argument, integrity can be considered as business assets. Integrity can enhance business outputs and such assets are crucial to the operation and success of business operation. Koehn (2005) in her writing: Integrity as Business Assets, stressed the need for integrity. He pointed out that in today's organization, employees seldom see executive with integrity. Koehn cited new survey by the Walker Consulting Firm to prove his point. According to such the survey, that less than half of 
workers thought their senior leaders were people of high integrity. However, integrity is not an instrumental value but it must be an intrinsic value of the managers or executives. Often time integrity is used to achieve the ends but it is not really the inner value of the person. Integrity should be a character of the executive, not treated as instruments used to achieve certain purpose. Though Koehn sees integrity as an intrinsic value or it may be called the intactness of the character of person, however Planalto (2012) sees integrity not only as an intrinsic value or psychological harmony but it has also a practical value. Such value must be practiced in daily life. According to him that persons of integrity remain true to their commitment in action and deliberation. He suggests that practical integrity captures other features of character and action often related to ascription of integrity.

Expanding the meaning of integrity, Cox and Caze (2013) argued that integrity is attributed to various parts of a person's life such as professional, intellectual and moral integrity. Integrity refers to general character. Since it is the general character of the person, integrity would mean how a person exhibit integrity throughout his life. In other words, the main concern of integrity is how a person of integrity lives his life which can be exhibited in his/her personal, professional and intellectual life. Therefore, integrity is now classified into two kinds. One aspect of integrity is related to a formal relation one has to oneself, and the other aspect is related to an important way to acting morally.

\section{On integrity and job satisfaction}

Few literatures have been written along this line. However, we try to examine some available literatures along job satisfaction and integrity. It has been stated above that integrity is an essential value of the organization. It has been emphasized that practicing such values naturally will improve organizational climate, work environment and finally job satisfaction. Callaway (2006) argues that lack of it organizational communication and organizational performance may decline. Integrity and trust have been identified as a crucial ingredient for organizational effectiveness and it has been also established that there is a linkage between trust and job satisfaction in private organizations.

Integrity in the organization is started with manager. It must be a personal value of the manager that has to be seen in action. A manager who has the integrity helps employees, listens to their innovative ideas, motivates them, directs them, and remains open and friendly with them. In that regard, manager's integrity helps an organization in achieving short term and long-term goals because manager's value plays a significant role in employee's involvement. It inspires and motivates employees to engage. See to it that ethical code that is set by the manager must be lived by himself and acceptable by the employees. All actions and decisions must be based on the value of integrity and it reflects the intensity of integrity of manager (Eby \&Lentz, 2006).

It cannot be denied that job satisfaction and manager's integrity has direct relationship. Actions and words of manager govern the action of employees. If manager's words depict trust and honesty, employees will follow the manager. Therefore, integrity is significant to the employer-employee relationships. When there is trust, there can be good relationship and when there is good relationship, employees behave ethically and use ethical ways to complete their task and achieve organizational objectives (Kosgaard 2006). Lack of it can weaken the performance of an organization because employees can be dissatisfied and demotivated. When the employees perceive unfairness and inequality, they will adopt unethical behavior (Cropanzano \& Mitzchel, 2005). Building trust relationship between employees and employer are necessary to achieve the objective of the organization. Employer and employees can work as a team. Team work creates a friendly and cooperative environment that makes employees and employer emotionally attach with each other. Emotional attachment builds a trust based relationship between employees and manager. In the light of this theory, manager and employees share a formal relationship. Both work for the betterment of the organization. Social exchange theory exchanges social benefits such as support, advice, etc. (Grant \& Sumanth, 2009)

\section{Related studies}

\section{On integrity and job satisfaction}

Studies have proven that integrity influences job satisfaction or dissatisfaction. It affects the organization positively and negatively depending on how integrity is exercised by those who lead the 
organization. Along this line, there have been a lot of studies along integrity and how it affects job satisfaction of employees. Some researchers argue that leaders need integrity to be effective, while others argue that only results matter, not how you get them. Few have empirically examined the impact of integrity on leadership effectiveness. Hooijberg and Lane (2005) examined the impact of leadership behaviors on effectiveness as well as values such as integrity, flexibility and conformity on effectiveness. They found that the values of integrity and flexibility have a significant impact on effectiveness over and above the impact of various leadership behaviors. Going into the same line of interest of study, Davis \& Rothstein (2006) conducted a study entitled, The Effect of the Perceived behavioral Integrity of Managers on Employee Attitudes: A Meta-Analysis. It tried to examine the relationship between perceived behavioral integrity of managers and the employee's job satisfaction, organizational commitment, satisfaction with the leader and attitude toward the organization. Results indicate a strong positive relationship between perceived behavioral integrity of managers and employee's attitudes toward the organization. From such finding, the study concluded that behavioral integrity should be given serious attention by those who are in the position of leadership. Lack of integrity would result to reducing organizational commitment and dissatisfaction. This finding was also supported by the study Protass (2007) who tried to assess the value of integrity of managers and how it affects employee's attitude toward the organization and their commitment toward the organization. The study concluded that perceived behavioral integrity (PBI) was positively related to job satisfaction and commitment to the organization but negatively related to stress, poor health, and absenteeism. It means that lack of integrity does not affect stress and poor health of employees.

Following the same lead, Yammarino and Palanski (2011) also introduced a similar study on the impact of behavioral integrity of managers on follower job performance, follower's behavioral integrity. Findings from the studies indicated that leader behavioral integrity was not directly related to follower job performance, but it can affect trust in the leader and follower satisfaction with the leader. It was only the integrity of employees themselves that has a relationship toward job performance. Therefore, Somer (2001) recommended that integrity should be written in the manual of the organization to guide the behavior of its employees.

\section{Research methodology}

The nature of this study was a quantitative study. Therefore, this chapter presents the research design used in this study, data gathering instruments, population, locale of the study, data gathering procedures and statistical treatment of data.

\section{Research design}

Since the study was a quantitative research, thus, the study used descriptive method of research to assess the level of integrity of administrators. Descriptive research assesses, determines and reports the way things are. It involves recording and description, analysis and interpretation of things or conditions that now exists. In other words, it describes the data that have been collected on research sample, describes "what is" about the data.

The first problem was to find out the level of integrity of administrators of Divine Word Colleges in Northern Province in terms of self-integration. This was answered by computing the weighted means. The overall mean rating was computed.

The second problem was to find out the level of integrity of administrators a long maintenance of identity. The data was gathered and the weighted mean will be computed.

The third problem was to find out the level of integrity of administrators in terms of standing up for something. The answers of this problem were computed using certain statistical method to determine its weighted mean.

The fourth problem was to determine the level of integrity of administrators a long with moral purpose. The answer of this problem was gathered and the weighted mean will be computed.

The fifth problem was to determine the level of job satisfaction of employees of three colleges of Northern Province. Their answers were gathered and the weighted mean was computed.

The sixth problem was to find out the impact of integrity as a whole to the job satisfaction level of employees. This was computed by using weighted mean. 
Texila International Journal of Academic Research

Volume 4, Issue 1, Jun 2017

\section{Locale of the study}

The study was conducted in the Divine Word Colleges in Northern Province which include Divine Word College of Bangued (3), Divine Word College of Vigan (1) and Divine Word College of Laoag (2). These three colleges are within the governance of SVD Northern Province.

\section{Population}

The population of the study was taken from the employees of three colleges run by the Society of the Divine Word of Philippines Northern Province. Since the population of the study was small, so the total enumeration was used in which all employees of the three colleges were taken as the respondents of the study. Total enumeration was taken based on the judgment of the researcher to meet the objective of the study.

\section{Data gathering instruments}

The study utilized questionnaires. The questionnaires were distributed to employees of three SVD Colleges in Northern Province. The questionnaires were consisted of five parts. First part is demographic profiles of employees of three Divine Word Colleges. Second part is self-integration questionnaires. Third part is maintenance of identity and fourth part is moral purpose. Last part is employees' job satisfaction.

\section{Data gathering procedures}

In the process of data gathering, the researcher sent letters to the Presidents of the three colleges in the Northern Province, Philippines requesting the Presidents to allow the researcher to flow his questionnaires in his college. The researcher personally met the Presidents and employees and requested them to answer the questionnaires.

The retrieval of questionnaires was arranged between the President's representative and the researcher with the help of employees and faculty of the three colleges.

\section{Statistical treatment of data}

In consistent with the study as descriptive research, therefore descriptive statistics was used to measure frequency distribution and percentage and the weighted mean.

Frequency distribution and percentage was used to describe the profile of the employees the three colleges, while weighted mean was used to describe the integrity in terms of self-integration, maintenance of identity, standing up for something and moral purpose. To measure the relationships between variables, Pearson $\mathbf{r}$ was used. The following ranges of values with their descriptive interpretation were used:

\begin{tabular}{|l|l|l|}
\hline Scale & Range of Weighted means & Descriptive interpretation \\
\hline 5 & $4.21-5.00$ & Excellent/ Very Great Extent \\
\hline 4 & $3.41-4.20$ & Very Good/ Great Extent \\
\hline 3 & $2.61-3.40$ & Good/Moderate \\
\hline 2 & $1.81-2.60$ & Fair/ Limited Extent \\
\hline 1 & $1.00-1.80$ & Poor/Very Limited E \\
\hline
\end{tabular}

\section{Findings}

Problem 1: What is the level of integrity of administrators of Divine Word Colleges in the Northern Province, Philippines in terms of self-integration? 
Table 1. The level of integrity of administrators in terms of self-integration.

\begin{tabular}{|l|l|l|l|l|}
\hline & 1 & 2 & 3 & Total \\
\hline $\begin{array}{l}\text { 1. School administrators demonstrate the school's values in their daily } \\
\text { activities and behaviors }\end{array}$ & 3.53 & 3.35 & 2.93 & 3.27 \\
\hline $\begin{array}{l}\text { 2. The administrators consistently implement the policies of the school, } \\
\text { not only for the employees but also for himself }\end{array}$ & 3.36 & 3.28 & 2.92 & 3.19 \\
\hline $\begin{array}{l}\text { 3. The administrators have not been damaged by any accusation of } \\
\text { corruption and other ethical issues. }\end{array}$ & 3.59 & 3.48 & 2.95 & 3.34 \\
\hline $\begin{array}{l}\text { 4. Administrators make decision purely for the interest of the school, } \\
\text { not for personal interest }\end{array}$ & 3.33 & 3.42 & 2.95 & 3.23 \\
\hline $\begin{array}{l}\text { 5. The administrators are firm in their decisions when they believe it is } \\
\text { the right thing to do. }\end{array}$ & 3.31 & 3.44 & 3.15 & 3.30 \\
\hline $\begin{array}{l}\text { 6. Administrators walk the talk } \\
\text { 7. Administrators play of role model to their employees when it comes } \\
\text { to moral conduct and commitment to duties and responsibilities. }\end{array}$ & 3.39 & 3.11 & 2.85 & 3.06 \\
\hline $\begin{array}{l}\text { 8. Administrators have been always objectives and honest when they } \\
\text { are dealing with their employees. }\end{array}$ & 3.28 & 3.30 & 2.97 & 3.18 \\
\hline As a Whole & $\mathbf{3 . 3 8}$ & $\mathbf{3 . 3 4}$ & $\mathbf{2 . 9 5}$ & $\mathbf{3 . 2 2}$ \\
\hline
\end{tabular}

Legend:

4.21-5.00 : Excellent/Very Great Extent

3.41-4.20 : Very Good/Great Extent

2.61-3.40: Good/Moderate

1.81-2.60 : Fair/ Limited Extent

1.00-1.80: : Poor/Very Limited Extent

As a whole, the study found that the integrity of administrators along self-integration was rated at the 3.22 which is translated as good or moderate. In all questions, the administrators were rated within the range of good or moderate. No one school was rated at the range of very good or great extent.

Problem 2: What is the level of integrity of administrators of Divine Word Colleges in Northern Province in terms of maintenance of identity?

Table 2. The level of integrity of administrators along maintenance of identity

\begin{tabular}{|c|c|c|c|c|}
\hline & 1 & 2 & 3 & Total \\
\hline $\begin{array}{l}\text { 1. The administrators are committed to pursue objectives of } \\
\text { the school as prescribed in the school vision-and mission } \\
\text { statement }\end{array}$ & 3.52 & 3.57 & 3.10 & 3.40 \\
\hline $\begin{array}{l}\text { 2. The administrators always fulfill their promises to their } \\
\text { employees }\end{array}$ & 3.39 & 3.11 & 2.95 & 3.15 \\
\hline $\begin{array}{l}\text { 3. The administrators trust their employees and recognize the } \\
\text { contribution of their employees }\end{array}$ & 3.46 & 3.24 & 3.05 & 3.25 \\
\hline $\begin{array}{l}\text { 4. The administrators are committed to the development of the } \\
\text { welfare of their employees }\end{array}$ & 3.29 & 3.33 & 2.92 & 3.18 \\
\hline $\begin{array}{l}\text { 5. The administrators maintain a harmonious relationship with } \\
\text { the employees }\end{array}$ & 3.42 & 3.32 & 2.95 & 3.23 \\
\hline $\begin{array}{l}\text { 6. The administrators and employees trust each other through } \\
\text { an open line communication }\end{array}$ & 3.38 & 3.22 & 2.85 & 3.15 \\
\hline $\begin{array}{l}\text { 7. The administrators are committed to pursue quality } \\
\text { education as promised to students and parents. }\end{array}$ & 3.54 & 3.56 & 3.08 & 3.40 \\
\hline $\begin{array}{l}\text { 8. The administrators are faithful and on time going to their } \\
\text { offices as time scheduled for the employees }\end{array}$ & 3.40 & 3.32 & 2.89 & 3.20 \\
\hline $\begin{array}{l}\text { 9. The administrators put more priority to their main job } \\
\text { assigned to them than to their personal business }\end{array}$ & 3.46 & 3.43 & 3.00 & 3.29 \\
\hline As a Whole & 3.42 & 3.34 & 2.97 & 3.25 \\
\hline
\end{tabular}


Texila International Journal of Academic Research

Volume 4, Issue 1, Jun 2017

Based on the data presented above, taken as a whole, it is found that the value of integrity in terms of maintenance of identity is 3.25 which means good or moderate. In all questions, the administrators were rated within the same range of interpretation.

Problem 3: What is the level of integrity of administrators of Divine Word colleges in Northern Province in terms of standing up for something?

Table 3. The level of integrity in terms of standing up for something/social virtue

\begin{tabular}{|l|l|l|l|l|}
\hline & 1 & 2 & 3 & Total \\
\hline $\begin{array}{l}\text { 1. The administrators stand by their decision that is in the } \\
\text { interest of the school even if it is unpopular }\end{array}$ & 3.44 & 3.35 & 2.98 & 3.26 \\
\hline $\begin{array}{l}\text { 2. The administrators act consistently with the previous } \\
\text { decisions, despite of the pressures, no change of mind } \\
\text { when they know it is the best decision they made }\end{array}$ & 3.46 & 3.31 & 2.90 & 3.22 \\
\hline $\begin{array}{l}\text { 3. The administrators do not give in to pressures even if } \\
\text { they know that it will be a risk for their position. }\end{array}$ & 3.38 & 3.26 & 3.08 & 3.24 \\
\hline $\begin{array}{l}\text { 4. The administrators stand for what they believe in and } \\
\text { defend it even it means he/she is going to be removed. }\end{array}$ & 3.46 & 3.28 & 3.07 & 3.27 \\
\hline $\begin{array}{l}\text { 5. The administrators are committed to what is best for the } \\
\text { school, employees and themselves. }\end{array}$ & 3.48 & 3.37 & 3.11 & 3.32 \\
\hline $\begin{array}{l}\text { 6. The administrators are not easily swayed by popular } \\
\text { opinion and abandon their interest for the school. }\end{array}$ & 3.52 & 3.33 & 3.08 & 3.31 \\
\hline $\begin{array}{l}\text { 7. The administrators stick to what is right and good even } \\
\text { it means that they would be abandoned. }\end{array}$ & 3.53 & 3.33 & 3.11 & 3.33 \\
\hline $\begin{array}{l}\text { 8. The administrators are not afraid of confronting } \\
\text { employees when they know there was something } \\
\text { wrong. }\end{array}$ & 3.47 & 3.39 & 2.93 & 3.26 \\
\hline As a Whole & $\mathbf{3 . 4 7}$ & $\mathbf{3 . 3 3}$ & $\mathbf{3 . 0 4}$ & $\mathbf{3 . 2 8}$ \\
\hline
\end{tabular}

As gleaned from statistical table, the integrity of administrators a long standing up for something was evaluated with the mean of $\mathbf{3 ~ . 2 8}$ which is interpreted as good or moderate. Consistently the total computed value of each questions were rated within the same range of interpretation which is good or moderate.

Problem 4: What is the level of integrity of administrators of Divine Word colleges in Northern Province in terms of moral purpose?

Table 4. The level of integrity along moral purpose

\begin{tabular}{|l|l|l|l|l|}
\hline $\begin{array}{l}\text { 1. The administrators talk to their employees on how to do } \\
\text { their job in ethical manner }\end{array}$ & 3.60 & 3.53 & 3.03 & 3.39 \\
\hline $\begin{array}{l}\text { 2. The administrators are concerned with the work values of } \\
\text { their employees and help them to inculcate moral values in } \\
\text { their work by establishing moral code of conduct in their } \\
\text { employees' manual }\end{array}$ & 3.67 & 3.58 & 3.08 & 3.44 \\
\hline $\begin{array}{l}\text { 3. The administrators regularly show that she/he cares about } \\
\text { integrity and the school's values by not allowing anomalous } \\
\text { transactions. }\end{array}$ & 3.49 & 3.44 & 3.07 & 3.33 \\
\hline $\begin{array}{l}\text { 4. The administrators expect the people report to him/her } \\
\text { ethically }\end{array}$ & 3.64 & 3.50 & 3.11 & 3.42 \\
\hline $\begin{array}{l}\text { 5. The administrators take action immediately if there are } \\
\text { moral issues facing employees. }\end{array}$ & 3.50 & 3.34 & 3.02 & 3.29 \\
\hline $\begin{array}{l}\text { 6. The administrators care about moral development of } \\
\text { employees by introducing some activities that enhance their } \\
\text { moral values }\end{array}$ & 3.52 & 3.34 & 3.07 & 3.31 \\
\hline
\end{tabular}




\begin{tabular}{|l|l|l|l|l|}
\hline $\begin{array}{l}\text { 7. The administrators always treat their employees ethically } \\
\text { and respectfully }\end{array}$ & 3.59 & 3.57 & 3.05 & 3.40 \\
\hline $\begin{array}{l}\text { 8. The administrators do not compromise with moral issues } \\
\text { and taking strong disciplinary measures to prevent } \\
\text { immorality }\end{array}$ & 3.53 & 3.41 & 3.18 & 3.38 \\
\hline As a Whole & $\mathbf{3 . 5 7}$ & $\mathbf{3 . 4 6}$ & $\mathbf{3 . 0 8}$ & $\mathbf{3 . 3 7}$ \\
\hline
\end{tabular}

Legend

4.21-5.00 : Excellent/ Very Great Extent

3.41-4.20 : Very Good/ Great Extent

2.61-3.40 : Good/Moderate

1.81-2.60 : Fair/Limited Extent

1.00-1.80 : Poor/Very Limited Extent

As presented on the table, it shows that as a whole the integrity of administrators in terms of moral purpose were rated at the mean of 3.37 which is interpreted as good or moderate. Almost all questions were rated at the same range of interpretation. The rating still does not seem to reflect the good picture of religious run schools.

Problem 5: What is the level of job satisfaction of employees of Divine Word colleges in the Northern Province?

Table 5. The level of job satisfaction of employees

\begin{tabular}{|l|l|l|l|l|}
\hline & 1 & 2 & 3 & Total \\
\hline 1. I am generally satisfied with my current job & 3.79 & 3.79 & 3.10 & 3.50 \\
\hline 2. In general, I like the work I do & 3.94 & 4.03 & 3.38 & 3.78 \\
\hline 3. All in all, I like the working environment of the school & 3.49 & 3.53 & 3.02 & 3.35 \\
\hline $\begin{array}{l}\text { 4. I understand the long-term strategy of the school because it } \\
\text { is communicated to us employees }\end{array}$ & 3.41 & 3.39 & 2.95 & 3.25 \\
\hline 5. My administrators have good human relations & 3.40 & 3.55 & 2.97 & 3.31 \\
\hline $\begin{array}{l}\text { 6. The communication channel in this school is clear and } \\
\text { effective. }\end{array}$ & 3.20 & 3.40 & 2.84 & 3.15 \\
\hline $\begin{array}{l}\text { 7. I am satisfied that all employees are cooperating when it } \\
\text { comes to common activity. }\end{array}$ & 3.34 & 3.33 & 3.08 & 3.25 \\
\hline $\begin{array}{l}\text { 8. I am happy because my work and my accomplishment are } \\
\text { recognized. }\end{array}$ & 3.27 & 3.46 & 2.93 & 3.22 \\
\hline 9. I set goals when performing tasks given to me & 3.82 & 3.89 & 3.41 & 3.71 \\
\hline 10. My job is important to me & 4.20 & 4.32 & 3.52 & 4.01 \\
\hline 11. I am satisfied because training and development is provided. & 3.28 & 3.55 & 3.08 & 3.30 \\
\hline 12. I have enough freedom and authority to carry out my tasks & 3.66 & 3.64 & 3.20 & 3.50 \\
\hline 13. I have security of tenure in this school & 3.68 & 3.72 & 3.13 & 3.51 \\
\hline 14. I am happy with the spirit of community in this school & 3.66 & 3.64 & 2.92 & 3.40 \\
\hline 15. I have good relations with my administrators & 3.54 & 3.71 & 3.11 & 3.46 \\
\hline 16. Employees in this school are treated well and respected & 3.49 & 3.53 & 3.03 & 3.35 \\
\hline $\begin{array}{l}\text { 17. I am satisfied with my work even though the pay is lower } \\
\text { than the public school }\end{array}$ & 3.51 & 3.51 & 3.00 & 3.33 \\
\hline As a Whole & $\mathbf{3 . 5 6}$ & $\mathbf{3 . 6 5}$ & $\mathbf{3 . 1 0}$ & $\mathbf{3 . 4 3}$ \\
\hline
\end{tabular}

Legend

4.21-5.00 : : Excellent/ Very Great Extent

3.41-4.20 : Very Good/ Great Extent

2.61-3.40 : Good/Moderate

1.81-2.60 : Fair/Limited Extent

1.00-1.80 : Poor/Very Limited Extent 
Texila International Journal of Academic Research

Volume 4, Issue 1, Jun 2017

As it is shown in the table, it reveals that as a whole, employees from three colleges were rated with the average mean of 3.43. It is interpreted as very good or to a great extent. This indicates that employees are satisfied to a great extent, though they are not really satisfied to a very great extent. This just means that majority of employees are satisfied with their jobs. Employees like their work, set their own goals to their work, see the importance of their work to their own life, are free to carry out their duties and responsibilities, have security of tenure, and experience a good human relations. The data also reveals that some improvements need to be done along working environment, dissemination of information in line with long-term objectives, human relations, communication channel, cooperation among employees, employees' recognition, training and development, community spirit, fair treatment, and the salary.

Table 6. Summary Table of Administrators' Integrity by Schools

\begin{tabular}{|l|l|l|l|l|}
\hline Variables & 1 & 2 & 3 & Total \\
\hline Self-integration & 3.38 & 3.34 & 2.95 & 3.22 \\
\hline Maintenance of identity & 3.42 & 3.34 & 2.97 & 3.24 \\
\hline Standing up for something & 3.47 & 3.33 & 3.04 & 3.28 \\
\hline Moral purpose & 3.57 & 3.47 & 3.08 & 3.37 \\
\hline As a whole & 3.46 & 3.37 & 3.01 & 3.27 \\
\hline
\end{tabular}

Legend

4.21-5.00 : Excellent/ Very Great Extent

3.41-4.20 : Very Good/ Great Extent

2.61-3.40 : Good/Moderate

1.81-2.60 : Fair/ Limited Extent

1.00-1.80 : Poor/Very Limited Extent

Looking at the rating of individual schools, the table shows that school number one is evaluated as the highest mean rating among the three schools with the mean of 3.46 which is interpreted as very good or to a great extent. This concludes that school number one is better than the two other schools. The two schools, number 2 and 3 were evaluated with the mean of 3.37 and 3.01 which is interpreted as "good or moderate". Such finding indicates that the administrators of the two schools have more things to do to improve its integrity.

Table 7. Summary on Administrators' Integrity as a Whole

\begin{tabular}{|l|l|}
\hline Self-Integration & 3.22 \\
\hline Maintenance of Identity & 3.24 \\
\hline Standing up for Something & 3.28 \\
\hline Moral Purpose & 3.37 \\
\hline As a whole & 3.27 \\
\hline
\end{tabular}

Legend

4.21-5.00 : Excellent/ Very Great

Extent

3.41-4.20 : Very Good/ Great Extent

2.61-3.40: Good/Moderate

1.81-2.60 : Fair/ Limited Extent

1.00-1.80 : Poor/Very Limited Extent

From the summary table, it is clearly seen that overall ratings for administrators' integrity for all schools is rated with the mean rating of 3.27 with the interpretation of "good or moderate". All variables of organizational integrity are evaluated as "good or moderate". It concludes that as a whole, the schools have not really shown their integrity to the employees and it just means that there are still a lot of improvements needed to be done to improve their integrity. Administrators' integrity matters much to the organization's or school's integrity. 
Problem 8: Is there no significant relationship between the value of organizational integrity and the job satisfaction of employees?

Table 7. Coefficient correlation between Administrators' integrity and job satisfaction

\begin{tabular}{|l|l|}
\hline Administrators' Integrity & Job satisfaction \\
\hline Self-Integration & $.774^{* *}$ \\
\hline Maintenance of Identity & $.717^{* *}$ \\
\hline Standing up for Something & $.692^{* *}$ \\
\hline Moral Purpose & $.730^{* *}$ \\
\hline
\end{tabular}

** Correlation is significant at the 0.01 level (2-tailed)

The table on the correlation between administrators' integrity and job satisfaction of employees reveals that all four factors measuring administrators' integrity have a significant relationship with the job satisfaction of employees. This finding concludes that satisfactions of employees are not only caused by monetary rewards or salary but the integrity of administrators has a great contributing factor to the job satisfaction of employees. It just means that when the level of moral integrity of administrators is at the level of "good or moderate", then definitely the level of job satisfaction is also at the level of "good or moderate". Definitely improving job satisfaction of employees necessarily means improving the moral integrity of administrators. The value of integrity has to be the guiding principles and practice of the administrators if they want to improve job satisfaction. Thus, the hypothesis of this study is rejected.

\section{Conclusion}

Since the purpose of the study was to determine the level of administrators' integrity and how does it affect job satisfaction, the study concludes that the administrators' integrity is good or moderate and there is a significant relationship between administrators level of integrity and job satisfaction of employees of the three schools. It just means that job satisfaction is caused by the administrators' integrity. To improve job satisfaction of employees is to improve administrators' organizational integrity.

\section{Recommendation}

Based on the findings of this study, the following are the recommendations:

1. On Organizational integrity. The top management must take a step to improve their integrity by constantly monitoring their ethical behavior, living the institutional values, implementing policies consistently, avoiding corruption, avoiding personal interest, being decisive, leading by example, being objective and honest. In line with maintenance of identity, the study recommends that the administrators should commit themselves to the school's vision and mission, fulfill their promises, trust their employees, give attention to the welfare of the employees, build harmonious relationship, have open line communication, pursue quality of education, and attend their office on time. In terms of improving their social virtue, the administrators should learn to stand by their decision, act consistently with their decisions despite of pressures, stand up for what they believe in and confronting employees when they committed immorality. While along moral purpose, the administrators need to advice employees on how to do their job on ethical manner, give attention to the moral values of the employees in the workplace, provide ethical code of conduct and implement them, avoid anomalous transaction, demand ethical behavior in dealing with each other, take action with those who have moral issues, provide training for moral development, treat employees ethically and establish disciplinary measures to prevent unethical behavior.

2. In terms of Employees' Job satisfaction. The administrators need to give attention on the following factors such as: conducive working environment, dissemination of information about what is going on in the school, just and ethical treatment, increasing salary and benefits, human relations, recognition, clear objective given to employees, training and development, empowerment, security of tenure, respect and living the community spirit. 
Texila International Journal of Academic Research

Volume 4, Issue 1, Jun 2017

3. Selection of Administrators. The study recommends that there must be a special screening committee to select and recommends persons to occupy a position. One of the criteria to be included in the selection is the values of the person, particularly the value of integrity.

4. Regular evaluation and $\mathbf{3 6 5}$ degree feedbacks. Top administrators must be evaluated regularly regarding their performance. Besides, evaluations are not only performed by the employees but by other sectors that are affected by their services particularly the students, the parents and even related government offices (CHED or DepEd).

5. Training and seminars along integrity. The administrators invite experts to conduct training and seminars to enhance their moral values.

6. Orientation. It is important for the newly appointed administrators to be oriented on their main roles as leaders in the Catholic institution. The existence of the Catholic institutions is for evangelization. The biblical values must be the values of the administrators in fulfilling their duties and responsibilities.

7. Seminar on ethical and servant leadership must be conducted. Additional recommendations come from the employees are attached at the last page of this study.

\section{References}

[1]. Allen, T.D., Eby, L.T \& Lentz, E. (2006). Mentorship Behaviors and Mentorship Quality, Associated with Mentoring Programs. Journal of Applied Psychology. http://www.docstoc.com/Docs/Document-DetailGoogle.aspx?doc_id=104461839

[2]. Callaway, L. Ph. (2006). The Relationship between Organizational Trust and Job Satisfaction. Boca Raton: Florida USA • 2007ISBN: 1-58112-352-3

[3]. Calhoun, Ch. (1995). 'Standing for Something,' Journal of Philosophy, XCII: 235-260.

[4]. Cox, D \& La, C. M. (2013, 2017). Integrity. Retrieved from

http://plato.stanford.edu/entries/integrity/

[5]. Davis, L. A \& Rothstein, R. H. (2006). The Effects of the Perceived Behavioral Integrity of Managers on Employee Attitudes: A Meta-Analysis. Journal of Business Ethics 67 (4):407 - 419. http://philpapers.org/rec/DAVTEO-5

[6]. Duggar, W. J. (n.d). The role of integrity in individual and effective corporate leadership. Journal of Academic and Business Ethics: Holy Family University. Retrieved, October 1, 2015 at

http://www.aabri.com/manuscripts/10504.pdf

[7]. Edmonds, Ch. (2001). Enron Files for Chapter 11 Bankruptcy Protection.

http://www.thestreet.com/story/10004757/1/enron-files-for-chapter-11-bankruptcy-protection.html

[8]. Flannery, A. Ed. (1982). Vatican Council II, More Post Conciliar Documents. Paulines Publishing House Daughters of St. Paul: Pasay City, Manila, Philippines

[9]. Frankfurt, H. (1971). 'Freedom of the Will and the Concept of a Person,' Journal of Philosophy, LXVIII: 5-20.

[10]. Great Places to Work Institute (GPWI) (n.d.). Best Companies Lists. Retrieved from http://www.greatplacetowork.com/best/index.php

[11]. Halfon, Mark. (1989). Integrity: A Philosophical Inquiry, Philadelphia: Temple University Press.

[12]. Howe, A. (2011). The 11 Largest Bankruptcies in American History.

[13]. Business Insider. http://www.businessinsider.com/largest-bankruptcies-in-americanhistory-2011-11

[14]. Kaiser, R.B., \& Hogan, R. (2010). How to (and how not to) assess the integrity of managers. Consulting Psychology Journal: Practice and Research, 62(4), Dec 2010, 216-234.

[15]. Kaluturi, S. Bh. (2008). Job Satisfaction: An Empirical Study. Krishna University: India

[16]. Koehn, Daryl. (2005). Integrity as Business Assets. Journal of Business Ethics 58 (1-3):125 - 136. http://philpapers.org/rec/DAVTEO-5

[17]. Korsgaard, M., Brodt, S. \& Whitener, E. (2002). Trust in the Face of Conflict: the Role of Managerial Trustworthy Behavior and Organizational Context. Journal of Applied Psychology, 87: 312-319

[18]. Nillsen, R. (2005). The Concept of Integrity in Teaching and Learning. Journal of University Teaching and Learning Practice. The University of Wollongong. Retrieved, October 1, 2015 at http://jutlp.uow.edu.au/2005_v02_i03b/pdf/nillsen_006.pdf 
[19]. Paine, S. L. (1994). Managing for Organizational Integrity. Harvard Business Review. Retrieved, October 2, 2015 at https://hbr.org/1994/03/managing-for-organizational-integrity

[20]. O’Connor, P. (2014). Declaring Moral Bankruptcy. Retrieved from

https://www.psychologytoday.com/blog/philosophy-stirred-not-shaken/201410/declaring-moral-bankruptcy.

[21]. Pottras, J. D. (2007). Perceived Behavioral Integrity: Relationships with Employee Attitudes, Well-Being, and Absenteeism. Journal of Business Ethics: Springer Science \& Business Media.

[22]. Palanski, E. M. \& Yammarino, J. F. (2011). Impact of Behavioral Integrity on Follower Job Performance: A three-study examination. The Leadership Quarterly, Volume: 22, Issue: 4, Publisher: Elsevier Inc. retrieved from http://philpapers.org/rec/DAVTEO-5

[23]. Matthew Pianalto (2012). Integrity and Struggle. Philosophia 40 (2):319-336.

[24]. Planalto, M. (2012). Integrity and Struggle. Philosophie 40, 319-338. Philpapers: online research in Philosophy.

[25]. Rangapriya K.N. \& Barbara S. L. (n.d) Behavioral Integrity: How Leader Referents and Trust Matter to Workplace Outcomes. Journal of Business Ethics. Philpapers.org

[26]. Robert, H. R. \& Lane, N. (2005). LEADER EFFECTIVENESS AND INTEGRITY: WISHFUL THINKING. IMD - International Institute for Management Development, Chemin de Bellerive 23: Switzerland. [27]. Schleicher, D. J., Watt, J.D. \& Greguras, Gary J. (2004). Reexamining the Job Satisfaction-Performance Relationship: The Complexity of Attitudes. Journal of Applied Psychology, Vol 89(1), Feb 2004, 165-177.

[28]. Sison, G. \& Jose A. (2008). A Corporate Governance and Ethics: An Aristotelian Perspective. Edward Elgar Publishing Limited: UK

[29]. Somers, J. M. (2001. Ethical Codes of Conduct and Organizational Context: A Study of the Relationship Between Codes of Conduct, Employee Behavior and Organizational Values. Journal of Business Ethics 30 (2):185 - 195 .

http://philpapers.org/rec/DAVTEO-5

[30]. Series Vatican Documents. 2012. The Sacred Congregation for Catholic Education. Paulines Publishing House: Philippines

[31]. Srivastva S. (1988). Executive Integrity: The Search for High Human Values in Organizational Life. New York: Jossey-Bass.

[32]. Scheid, K. (2010). Job Satisfaction: What is it? Why is It Important? How can You Get It? Best Christian Workplace Institute.

[33]. Stanford Encyclopedia of Philosophy. 2001. Integrity. Retrieved from https://plato.stanford.edu/entries/integrity/

[34]. The Code of Canon Law. (1983). Paulines Publishing House Daughters of St. Paul: Pasay City, Manila, Philippines

[35]. Valentine, S., Varca, P., \& Godkin, L. (2010). Positive Job Response and Ethical Job Performance. Journal of Business Ethics 91 (2):195 - 206. http://philpapers.org/rec/DAVTEO-5.

[36]. Verhezen, P. (2008). The (Ir) relevance of Integrity in Organizations. Public Integrity Journal. Retrieved, October 3, 2015 at

http://www.verhezen.net/thoughts_publications/Irrelevance\%20of\%20Integrity $\% 20 \mathrm{in} \% 20 \mathrm{Public} \% 20$ Integrity $\%$ 20Spring\%2008.pdf

[37]. Von, M.L. (2010). The Influence of Leadership Styles on Employees Job Satisfaction in Public Sector organization in Malaysia. International Journal of Business, Management and Social Sciences Vol. 2, No. 1, 2011, pp. 24-32. Retrieved, October 4, 2015.

[38]. Xiao, F. Sh. \& Froese, F. J. (2008). Work Values, Job Satisfaction and Organizational Commitment in China. Academy of International Business, Milan. https://aib.msu.edu/events/2008/BestPapers/AIB20080415.pdf. Retrieved, Octobe 6, 2015.

[39]. Williams, B. (1981). Moral Luck: Philosophical Papers 1973-1980, Cambridge: Cambridge University Press.

[40]. William, B. (1973)., Problems of the Self. Cambridge: Cambridge University Press. 